\title{
Opportunities and Challenges of Setting-Up an Articulate HACCP System in Export Slaughterhouses in Countries Emerging from Conflict: An Appraisal of North-Western Somalia
}

\author{
Castiello Massimo ${ }^{1}$, Wamalwa Kinyanjui ${ }^{1 *}$, Sophycate Njue $^{1}$, Gathuma Joseph $^{2}$, \\ Ombui Jackson Nyorangi ${ }^{2}$, Ogara William ${ }^{2}$ \\ ${ }^{1}$ Food and Agriculture Organization of United Nations, FAO Somalia, Nairobi, Kenya; ${ }^{2}$ Faculty of Veterinary Medicine, University \\ of Nairobi, Nairobi, Kenya. \\ Email: "wamalwakinyanjui@yahoo.com,kwam91@gmail.com,wamalwa.kinyanjui@fao.org
}

Received July 27 ${ }^{\text {th }}$ 2012; revised December $19^{\text {th }}$, 2012; accepted December $26^{\text {th }}, 2012$

\begin{abstract}
An investigation in North-Western Somalia (Somaliland) to determine opportunities and challenges of setting up a Hazard Analysis and Critical Control Points (HACCP) system to be adopted and complied with during operations in an export slaughterhouse was carried out for more than two years. A baseline and after intervention microbiological analysis was carried out on 500 wet and dry meat swab samples collected from carcasses from the slaughterhouse. The analysis was against total viable counts, E. coli counts and Salmonella species. It was established that after intervention through capacity building and supply of basic livestock slaughter equipments and tools, levels of carcass contamination reduced though not statistically significant. Slaughterhouse workers were trained on food safety quality assurance systems of good hygiene practices, standard operating procedures, sanitary standard operating procedures among others. Good opportunities of establishing HACCP system were high as the slaughterhouse had a ready supply of livestock for slaughter and high demand of Somalia small ruminant carcasses in the Middle East countries. However, the implementation faced severe challenges including lack of transport plane for carcasses to export market, frequent severe drought shocks, stiff competition from export of live livestock from Somalia, stiff competition from other countries exporting carcasses to Middle East countries; among others. These led to interruptions to operations and subsequent closure of the slaughterhouse impacting negatively on establishment of a vibrant operational HACCP system.
\end{abstract}

Keywords: HACCP; Good Hygiene Practices; Opportunities; Challenges

\section{Introduction}

The main aim of food manufacturers is to produce high quality and safe foods. To assure the safety of food, establishing a system based on a continuous management including total quality management, hygiene and good manufacturing practices is essential. Therefore, Hazard Analysis and Critical Control Point (HACCP) system should be examined and complied with in any food processing facility [1].

HACCP system is defined as a systematic scientific approach aimed at providing food production process quality assurance control. It is designed to prevent the occurrence of food safety public health hazards in processed foods by identifying, evaluating, preventing, eliminating, controlling or reducing hazards which are sig-

${ }^{*}$ Corresponding author. nificant for food safety to acceptable levels. It ensures that control measures are applied at any point in a food production chain where hazardous or critical situations for hazard contamination could occur [2,3].

A HACCP system is the surest way of ensuring food safety from farm-to-fork instead of depending on end product testing. Its goal is to prevent food safety public health hazards at the earliest possible point in the food production, processing or distribution chain. The HACCP approach can be applied right from harvest or production to the point of consumption. Adoption and implementation of HACCP system in addition to traditional meat inspection services and quality control activities would lead to a preventive quality assurance system in any slaughterhouse whether for domestic or export purposes. Export slaughterhouses that have adopted and incorporated the HACCP system in their production processes 
provide greater confidence to consumers about food safety to importing countries as well as to food safety regulatory authorities. This paper reviews the opportunities and challenges existing in Somaliland meat sub-sector in the adoption and compliance with HACCP system at the study target export slaughterhouse.

\section{Materials and Methods}

- Secondary data collection was done through review of literature at FAO Somalia office and search of information from the internet;

- Primary data was collected through collection of surface meat swab samples and carrying out microbeological laboratory analysis in Analabs Laboratory in Nairobi, Kenya and data analysis. This was complemented through supply of livestock slaughter equipments and training of abattoir workers of the target slaughterhouse in meat production quality assurance skills.

\section{Implementation Site}

The intervention activities were carried out in the expansive country of Somalia; in the independent state of Somaliland (north-western) (Figure 1). The study period ran from July 2008 to December 2010, for a period of two and a half years at H-Foods export slaughterhouse in Somaliland. This was purposively selected based on prevailing security status, being the only operating export slaughterhouse, ease of communication and government export meat regulating institutions that are paramount to implementation of the HACCP system.

\section{Results and Discussion}

\subsection{First Round of Bacteriological Meat Swab Samples Analysis}

A total of 250 surface meat swab samples were collected

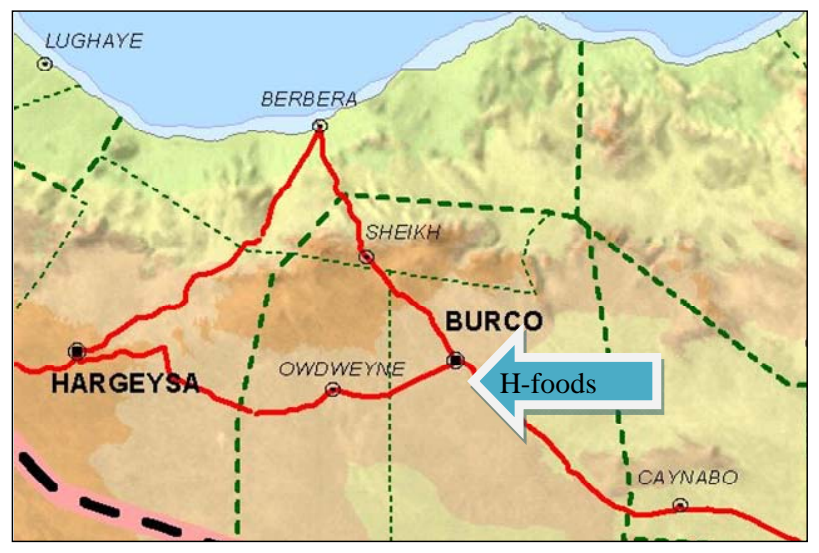

Figure 1. Map of Somaliland. from small ruminant carcasses slaughtered from $\mathrm{H}$-foods export slaughterhouse for the first round before intervenetion. The samples were analyzed against total viable counts (TVC), Escherichia coli and presence of Salmonella species. The analysis was done in Analabs Laboratory in Nairobi, Kenya. The results were compared with Gulf Cooperative Council (GCC) countries' microbiological performance criteria where Somalia meat is exported to. Table 1 shows GCC microbeological performance criteria.

\subsubsection{Total Viable Counts}

The first samples collected from carcasses slaughtered in the export slaughterhouse had average levels of contamination with total viable counts as shown in Table 2 according to Dubai Municipal microbiological performance criteria.

\subsubsection{E. coli Counts}

Samples collected from carcasses slaughtered in $\mathrm{H}$-foods export slaughterhouse had low levels of contamination with E. coli as shown in Table 3.

\subsubsection{Salmonella Species Presence}

None of the 250 surface meat swab samples analyzed tested positive for the presence of Salmonella species.

\subsection{Capacity Building and Trainings}

Interventions to establish a vibrant and verifiable HACCP system in selected H-foods-export slaughter-house started through human resource development and supply of some basic livestock slaughter tools and equipments. The human resource development focused on training both technical and non-technical personnel working in the export slaughterhouse in food quality assurance programs including Good Hygiene Practices (GHP), Standard Operating Procedures (SOP), Sanitary Standard Operating Procedures (SSOP), sound slaughtering techniques, safe recovery of hides and skins and carcass traceability (Table 2).

FAO Somalia and implementing partner organizations in collaboration with the Somaliland competent authorities supported these activities of capacity building of technical, non-technical and management staff of the export slaughterhouse in meat quality assurance practices. Moreover, FAO supplied the slaughterhouse with basic livestock slaughter equipments including stainless steel knives, stainless steel hooks, stainless steel receptacles, sharpening steels, meat transportation containers and provision of protective gear (gumboots, white coats, overalls, aprons, caps, chin masks and gloves for meat handlers) for slaughterhouse workers. 
Table 1. Dubai microbiological performance criteria.

\begin{tabular}{|c|c|c|c|c|c|}
\hline Microbiological test & Excellent $\left(\mathrm{cfu} / \mathrm{cm}^{2}\right)$ & $\operatorname{Good}\left(\mathbf{c f u} / \mathrm{cm}^{2}\right)$ & Fair $\left(\mathbf{c f u} / \mathrm{cm}^{2}\right)$ & Poor $\left(\mathbf{c f u} / \mathrm{cm}^{2}\right)$ & V. poor $\left(\mathbf{c f u} / \mathrm{cm}^{2}\right)$ \\
\hline TVC & $<200$ & $201-2000$ & $2001-20,000$ & $20,001-200,000$ & $>200,000$ \\
\hline E. coli & $<3$ & $3-10$ & $11-100$ & $101-1100$ & $>1100$ \\
\hline Salmonella & Nil & Nil & Nil & Nil & Present \\
\hline
\end{tabular}

Table 2. Total viable counts (TVC).

\begin{tabular}{ccccccc}
\hline Export Slaughterhouse & Total samples & \multicolumn{5}{c}{ Total Viable Counts (TVC) } \\
\hline \multirow{2}{*}{ H-Foods } & & Excellent & Good & Fair & Poor & Very poor \\
n & 250 & $98(32.2 \%)$ & $132(52.8 \%)$ & $12(4.8 \%)$ & $6(2.4 \%)$ & $2(0.8 \%)$ \\
\hline
\end{tabular}

Table 3. E. coli counts.

\begin{tabular}{cccccccc}
\hline Export slaughterhouse & Total samples & \multicolumn{3}{c}{ E. Coli count } \\
\hline & & Excellent & Good & Fair & Poor & V. poor \\
H-Foods & 250 & $232(93.6 \%)$ & $12(4.8 \%)$ & $4(1.6 \%)$ & $2(0.8 \%)$ & 0 \\
\hline
\end{tabular}

Slightly over 94 percent of slaughterhouse workers were trained in good hygiene practices during meat production in 2009 (Table 4). A few selected personnel were further trained in SOP and SSOP which are prerequisite requirements for the establishment of a HACCP system in any food production plant. Initial steps of assembling HACCP teams for the slaughter- house kicked off in mid 2009 after assessment of the slaughterhouse on how far its operation was compliant with hygiene standards during meat production and transportation to airport for airlifting to export markets.

The operations made steady progress in compliance with hygiene standards and improved their facilities in readiness for adoption and implementation of the HACCP system. However, taunting challenges beckoned at the door of the slaughterhouse which was forced to cease operations towards the end of 2009 due to force majeure circumstances [4].

\subsection{Second Round of Bacteriological Sample Analysis after Intervention}

\subsubsection{Total Viable Counts}

After training and supply of basic livestock slaughter equipments, meat contamination level was drastically reduced though not statistically significant as shown in Table 5.

\subsubsection{E. coli Counts}

Similarly, levels of E. coli contamination drastically dropped with nearly all carcasses being of excellent grade as shown in Table 6:

\subsection{Opportunities and Challenges}

\subsubsection{Opportunities}

At the time (2007-2009) of intervention by FAO and partnership organizations, the slaughterhouse operation was at its best.

The slaughterhouse had employed 61 staff on long term contracts and an additional 92 casual workers on a regular basis especially during pick production period of Hajj (annual Islamic pilgrimage to Mecca in Saudi Arabia).

The slaughterhouse processed 4500 - 7200 carcasses of 8 - $10 \mathrm{~kg}$ each per week translating to $18,000-28,400$ carcasses per month during pick months being exported before it closed doors in September 2009. Small ruminants for slaughter were readily supplied by Fasal Global Group Company that had been contracted to supply them regularly on demand. The demand of carcasses in United Arab Emirates, the main market was very high since consumers preferred small ruminants from Somalia due to their small size, organic production management and financial affordability.

Given the huge numbers of chilled small ruminant carcass exports from these study slaughterhouse, ready availability of livestock for slaughter in addition to having hired staff on a regular contractual basis either as permanent or casual, there was every opportunity of establishing a vibrant HACCP system in the facility in order to guarantee the quality and safety of meat from the slaughterhouse for end consumers.

\subsubsection{Challenges}

The adoption and compliance with an articulate HACCP 
system started facing a nosedive when operations of Daallo commercial airline that was transporting carcasses to United Arab Emirates (UAE) from Somalia discontinued operations towards the end of 2009. This led to the closure of the slaughterhouse in September 2009 [4].

However, the slaughterhouse temporarily resumed operations in July 2010 when Juba airlines started transporting their carcasses to UAE but closed doors for a second time at the beginning of December 2010 having exported a paltry 20,253 chilled ruminant carcasses during the five months of operation.

These challenges were further compounded by the lifting of trade ban on live livestock exports from Somalia to Kingdom of Saudi Arabia in October 2009. Consumers at destination markets had preference for live animals as compared to carcasses. This escalated the cost of livestock to an extent that the export slaughterhouse could no longer make ends meet [4].

Compounding the already fragile situation for the export slaughterhouse under study was the regular droughts that severely affected the livestock body conditions complicating availability of good quality carcasses as required at the export market. This was further complicated by the discovery of explosives on two cargo planes bound for the United States concealed in printer cartridges towards the end of 2010 from Yemen. This led to UAE banning any cargo from Somalia directly to its territory. This forced traders to divert carcasses to Oman by

Table 4. Number of personnel trained.

\begin{tabular}{ccccc}
\hline Slaughterhouse & Type of training & $\begin{array}{c}\text { No. of } \\
\text { workers }\end{array}$ & $\begin{array}{c}\text { No. } \\
\text { trained }\end{array}$ & $\begin{array}{c}\text { \% } \\
\text { trained }\end{array}$ \\
\hline & $\begin{array}{c}\text { GHP, sound slaughtering } \\
\text { techniques and } \\
\text { traceability }\end{array}$ & 153 & 143 & 94 \\
$\begin{array}{c}\text { H-foods } \\
\text { (Burao) }\end{array}$ & SSOP & & 40 & 26 \\
& SOP & 50 & 33 \\
\hline
\end{tabular}

Table 5. Total viable counts (TVC).

\begin{tabular}{ccccccc}
\hline $\begin{array}{c}\text { Export } \\
\text { Slaughterhouse }\end{array}$ & $\begin{array}{c}\text { Total } \\
\text { samples }\end{array}$ & \multicolumn{5}{c}{ Total viable counts (TVC) } \\
\hline & & Excellent & Good & Fair & Poor & $\begin{array}{c}\text { Very } \\
\text { poor }\end{array}$ \\
H-Foods & 250 & $\begin{array}{c}132 \\
(52.8 \%)\end{array}$ & $\begin{array}{c}117 \\
\text { (46.8\%) }\end{array}$ & $\begin{array}{l}(0.6 \%) \\
\text { (1) }\end{array}$ & 0 & 0 \\
\hline
\end{tabular}

Table 6. E. coli counts.

\begin{tabular}{ccccccc}
\hline $\begin{array}{c}\text { Export } \\
\text { slaughterhouse }\end{array}$ & $\begin{array}{c}\text { Total } \\
\text { samples }\end{array}$ & \multicolumn{5}{c}{ E. coli count } \\
\hline & Excellent & Good & Fair & Poor & V. poor \\
H-Foods & 250 & $\begin{array}{c}245 \\
(98 \%)\end{array}$ & $5(2 \%)$ & 0 & 0 & 0 \\
\hline
\end{tabular}

Juba airlines and then transported by road to UAE. This further escalated the operational costs in addition to increased carcass spoilage due to long period on the road. This led to a second time closure of the export slaughterhouse on 11th December 2010 being the last operational date when the investigation was being conducted [4].

The interrupted operations and frequent closure of the slaughterhouse led to an exodus of trained abattoir personnel to take up different employments or start personal businesses. Due to all the said constrains and force majeure challenges, it was a daunting task for FAO to successfully and sustainably assist the export slaughterhouse under the study to adopt and comply with a vibrant, operational and verifiable HACCP system in its infrastructural facilities and operations.

\section{Discussion}

Despite the enormous carcass export opportunities in addition to willingness by FAO Somalia and implementing partner organizations to support the implementation of an articulate HACCP system into the study export slaughterhouse, a series of challenges arising complicated the whole process.

Otherwise, implementation and operationalization of an articulate HACCP system in any food plant requires country stability, operational and strong regulatory authorities, steady and expanding markets and very minimal turn-over of trained abattoir personnel [5]. Wamalwa et al., 2011 has shown that training and capacity building have great impact on reducing meat contamination during production. Furthermore, expansion of facilities to accommodate the HACCP system compliant facilities and the ever rising food safety standards is of paramount importance. Regular capacity building and training of personnel in food quality assurance systems is one of the building blocks of establishing a sustainable HACCP system in any food industry [5].

\section{Acknowledgements}

Disclaimer: The views expressed in this paper are those of the authors and do not necessarily represent the position of FAO. The designations employed do not imply FAO's opinion concerning the legal status of any country, territory or area including the delimitation of its frontiers or boundaries.

The successful accomplishment of this study was made possible by many actors whose invaluable support deserves our heartfelt appreciation. Researchers would like to express their innermost appreciation to Graham Farmer and his successor, Luca Alinovi, the Officers in-charge of FAO Somalia for accepting and allowing us 
total access to FAO facilities, documents and resources that enabled accomplishment of the research work. The project manager of the EC project, Mr. Abdullahi Hussein and his successor, Dr. George Matete whose project sponsored the data collection are highly acknowledged. Mohammed Jama, Officer in-charge of FAO Hargeisa office, Somaliland is highly recognized for his invaluable support. Further to be acknowledged are laboratory technicians of Analabs Laboratory in Nairobi, Kenya especially, Mr Duncan Ndegwa who ensured that samples were analysed within 24 - 48 hours of collection, mostly at his inconvenience.

\section{REFERENCES}

[1] Australian Quarantine and Inspection Service, “A Guide for the Preparation of the Meat Safety Quality Assurance System (MSQA) for Fresh Meat \& Processed Meat Products," 2008.

http://www.daff.gov.au/_data/assets/pdf_file/0008/1292 84/msqa_2nd_ed.pdf

[2] B.Howlett, D. J. Bolton and C. O’Sullivan, “Development of Pre-Requisite Programmes and HACCP Principles for Irish Beef Slaughterhouses,” 2005.

http://www.teagasc.ie/publications/reportno1prerequisites. pdf

[3] L. Naresh, S. U. Merchant and N. C. Dhuldhoya, "Food Safety using HACCP Quality Management System,” 2006. http://www.lucidcolloids.com/pdf/584571394_haccp.pdf

[4] K. Wamalwa, M. Castiello, S. J. M. Munyua, R. G. Abdullahi, M. J. Gathuma, N. J. Ombui and M. E. Mogoa, "Commercialization of Meat Trade: The Potential Role of Private Sector and Capacity Building in Quality Assurance in Meat Export Trade from Regions of Somalia," International Research Journal of Microbiology, Vol. 3, No. 3, 2012, pp. 86-93. http://www.internationaljournals.org/IRJM

[5] W. Kinyanjui, C. Massimo, O. N. Jackson and G. M. Joseph, "Capacity Building; Benchmark for Production of Meat with Low Levels of Bacterial Contamination in Local Slaughterhouses in Somaliland," Tropical Animal Health and Production Journal, Vol. 44, No. 3, 2011, pp. 427-433.

www.unboundmedicine.com/.../Tropical_animal_health_ and_production 